Ethos : Jurnal Penelitian dan Pengabdian kepada Masyarakat, Vol 7, No.1, Januari 2019: 70-76

\title{
Workshop Media Animasi UntUK Meningkatkan Kreativitas GURU di KelURAHAN KeFAMENANU TENGAH
}

\author{
${ }^{1}$ Yohanis Ndapa Deda, ${ }^{2}$ Hermina Disnawati \\ 1,2 Pendidikan Matematika Universitas Timor

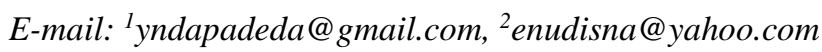

\begin{abstract}
Dedication was conducted for the purpose of raising creativity primary school teachers in Kelurahan Kefamanu Tengah in terms of find the area of square, rectangular, and triangular by using Microsoft PowerPoint. The methodology that was used in the event are: lectures, demonstration, direct practices, question and answer session, and assignment. Participants who take part in this workshop are 17 primary school teachers in Kelurahan Kefamanu Tengah. The subjects given to participants covering turn Microsoft PowerPoint, worksheets Microsoft PowerPoint, a function of tools in Microsoft PowerPoint, make and insert a picture, and moving pictures by using a custom animation. This workshop activities had a positive impact for SDN Kenari teachers. Before held workshop activities, they could neither make animation with the application Microsoft PowerPoint. After further workshop activities and held evaluation has been an increase in highly significant, more than $80 \%$ can make well animation of pictures.
\end{abstract}

Keywords: Animation, Microsoft PowerPoint, Teacher creativity.

\begin{abstract}
Abstrak. Pengabdian ini dilakukan dengan tujuan untuk meningkatkan kreatifitas guru sekolah dasar di Kelurahan Kefamenanu Tengah dalam hal menghitung luas persegi, persegi panjang, dan segitiga dengan menggunakan Microsoft PowerPoint. Metode yang digunakan dalam kegiatan ini adalah: ceramah, demonstrasi, praktik langsung, tanya jawab, dan penugasan. Peserta yang mengikuti workshop sebanyak 17 guru SD di Kelurahan Kefamenanu Tengah. Materi yang diberikan kepada peserta meliputi Mengaktifkan Ms. PowerPoint, Lembar Kerja Ms. PowerPoint, Fungsi dari Tools dalam Ms. PowerPoint, membuat dan Menyisipkan Gambar, dan menggerakkan gambar dengan menggunakan custom animation. Kegiatan workshop ini berdampak positif kepada guru-guru SDN Kenari di Kelurahan Kefamenanu Tengah. Sebelum diadakan kegiatan workshop, mereka sama sekali tidak dapat membuat animasi dengan program Microsoft PowerPoint. Setelah diadakan kegiatan worshop dan diadakan evaluasi terjadi peningkatan yang sangat signifikan, lebih dari $80 \%$ dapat membuat animasi gambar.
\end{abstract}

Kata kunci : Media Animasi, Microsoft PowerPoint, Kreatifitas Guru.

\section{Pendahuluan}

Globalisasi yang ditandai dengan perkembangan teknologi informasi yang sangat pesat mempengaruhi semua aspek kehidupan manusia termasuk dalam proses pembelajaran sekolah dasar.
Perkembangan media sebagai alat bantu dalam proses pembelajaran untuk memahami konsep-konsep dasar telah banyak mengalami perkembangan, terutama pada tingkat sekolah dasar. Penggunaan media animasi masih sangat kurang membuat guru sekolah dasar 
kurang kreatif dalam merancang kegiatan pembelajaran yang menarik. Sebagai akibatnya, minat belajar siswa menurun. Masalah utama yang terjadi pada guru-guru di sekolah mitra di Kelurahan Kefamenanu Tengah adalah kurang kreatif dalam membuat media pembelajaran yaitu media animasi. Untuk mengatasi masalah tersebut, maka perlu untuk melaksanakan kegiatan pengabdian yang melibatkan guru kelas yang ada di SDN Kenari Kelurahan Kefamenanu Tengah.

Media animasi yang dimaksud dalam kegiatan pengabdian ini adalah Media animasi dengan berbantuan program Microsoft Power Point 2007.Microsoft Power Point adalah program aplikasi presentasi yang merupakan salah satu program aplikasi di bawah Microsoft Office (Ena, 2010). Program ini dibuat untuk mendesain presentasi dalam seminar, workshop, penataran dan sebagainya oleh penyaji. Keuntungan dari program ini adalah sederhananya tampilan ikon-ikon. Ikonikon pembuatan presentasi kurang lebih sama dengan ikon-ikon Microsoft Word yang sudah dikenal oleh kebanyakan pemakai komputer. Program yang dihasilkanpun menarik. Program ini dilengkapi dengan animasi yang bukan hanya berlaku pada teks saja tetapi juga pada gambar bangun, garis dan sebagainya sehingga merupakan program yang interaktif. Inilah yang bisa dimanfaatkan sebagai media pembelajaran matematika. Dengan adanya animasi ini tentu akan menarik perhatian siswa. pembelajaran sebagai upaya untuk meningkatkan kreativitas guru yang akan diaplikasikan dalam proses belajar mengajar dalam kelas, untuk menarik minat siswa terhadap materi pelajaran. Agar guru dapat melaksanakan kegiatan belajar mengajar yang manarik dan tidak membosankan, maka sangat perlu untuk melatih keterampilan dalam membuat dan menggunakan media animasi sebagai sumber belajar. Media animasi ini dapat menampilkan gambar secara berurutan dari suatu peristiwa seperti kejadian yang sebenarnya (Shabrina, 2012: 20). Selain membuat proses pembelajaran dapat lebih menyenangkan, animasi juga dapat membuat siswa lebih lama mengingat materi dan gambar-gambar yang ditampilkan sehingga dapat memperjelas siswa dalam emahami materi yang diberikan.

Beberapa hasil penelitian yang mendasari pengabdian ini, yaitu Sudianto (2014) mengatakan bahwa adanya peningkatan aktivitas belajar siswa melalui penggunaan media animasi dalam pembelajaran matematika, peningkatan aktivitas belajar, dibuktikan dengan meningkatnnya nilai persentase aspek aktivitas belajar sebesar $80 \%$ (kategori sangat aktif), Badri dan Riasti (2013) mengatakan bahwa Hasil yang dicapai dari pembuatan Media Pembelajaran adalah siswa dapat memahami mata pelajaran TIK khususnya materi Power Point. dengan penerapan aplikasi ini dapat memudahkan proses belajar mengajar dan meningkatkan kualitas prestasi belajar. Purwandari, dkk (2016) mengatakan bahwa dalam pembuatan media animasi menunjukkan peningkatan kemampuan keterampilan guru Sekolah Dasar untuk mendukung 
pembelajaran di kelas. Hal ini ditunjukkan dari hasil proyek animasi yang dibuat oleh guru. Guru-guru berhasil menyelesaikan proyek pembuatan animasi sesuai dengan panduan yang telah diberikan di modul pelatihan. Alfiyah, dkk (2016) mengatakan bahwa kapasitas guru MINU Waru Sidoarjo dalam mengembangkan media pembelajaran berbasis teknologi informasi meningkat melalui penerapan pelatihan pengembangan media pembelajaran interaktif berbasis Ms. Power Point dengan memanfaatkan fitur-fitur yang tersedia di dalamnya melalui Pembuatan animasi pada slide dan gambar. Kemudian Karyati (2016) mengatakan bahwa terdapat pengaruh kreativitas guru terhadap pemanfaatan media pembelajaran dalam pembelajaran tematik di sekolah dasar.

Tujuan yang ingin dicapai pada pengabdian ini adalah Untuk meningkatkan keterampilan membuat media pembelajaran menggunakan Micro Soft PowerPoint. Output (luaran) yang dinginkan dalam pelaksanaan pengabdian ini adalah media Animasi yang menggunakan powerpoint (luas persegi, persegi panjang dan segitiga) dan 1 buah Jurnal Nasional tidak terakreditasi Ber-ISSN.

\section{Metode Penelitian}

Metode yang digunakan dalam pelaksanaan pengabdian ini adalah Pelatihan Praktek dengan tahap-tahap Perencanaan, Pelaksanaan, Evaluasi dan Refleksi (Arikunto, 2012).

1. Perencanaan a. Melakukan persiapan dengan berkoordinasi dengan sekolah mitra terkait waktu pelaksanaan.

b. Menyiapkan alat-alat dan bahan yang dibutuhkan saat pelatihan.

c. Melakukan bedah kurikulum Pada tahap ini, tim melakukan bedah kurikulum K-13 revisi tahun 2017 dengan tujuan untuk mengetahui kompetensi inti dan kompetensi dasar yang sesuai dengan jadwal kegiatan pengabdian mata pelejaran matematika.

2. Pelaksanaan

a. Melaksanakan Pelatihan Media Animasi di sekolah mitra bertempat di SDN Kenari. Melakukan Kerja Kelompok.

b. Pada langkah ini, salah satu guru mitra mengerjakan tugas yang diberikan secara kelompok menggunakan media animasi yang dikerjakan oleh guru mitra. Kemudian tim pengusul bersama guru mitra melakukan evaluasi.

3. Evaluasi dan refleksi

Kegiatan evaluasi dilakukan secara langsung oleh guru mitra dengan mengisi format evaluasi. Evaluasi terhadap materi, cara penyampaian dan manfaat bagi peserta. Proses evaluasi dilaksanakan untuk mengukur tingkat kreativitas guru dan dalam pelaksanaan kegiatan pengabdian dan menentukan langkah selanjutnya.

\section{Hasil dan Pembahasan}

Kegiatan Pelatihan dan Pendampingan Guru di sekolah mitra dilaksanakan pada bulan Agustus 2018 (1 bulan), yaitu Rabu Tanggal 29 dan Kamis 30 Agustus 2018 dengan jadwal 
menyesuaikan kegiatan guru di sekolah mitra yaitu SDN Kenari dalam bentuk pelatihan dan pendampingan bertujuan untuk meningkatkan kreativitas guru dalam membuat media pembelajaran berbasis Microsoft Power Point. Kegiatan ini dihadiri oleh para guru sebanyak 17 orang di SDN Kenari. Kegiatan dilaksanakan 2 kali sesuai permintaan mitra yaitu pada hari Rabu pukul 08.00-16.00 di SDN Kenari Kelurahan Kefamenanu Tengah. Kegiatan dimulai pada pukul 08.00 pagi dan berakhir pada pukul 16.00 dipandu oleh TIM Pengabdian dan 2 mahasiswa semester akhir. Secara keseluruhan kegiatan dibagi dalam 4 tahap antara lain: 1) Pembukaan, 2) Pelatihan 3) Evaluasi, dan 4) Penutupan yaitu penyerahan sertifikat bagi peserta pelatihan pada hari kedua. Kegiatan pengabdian masyarakat dilakukan dengan metode Pelatihan dan Pendampingan dapat diuraikan sebagai berikut

1). Pelatihan

Pelatihan dilakukan dua kali, yaitu hari pertama 29 Agustus 2018 dan hari kedua 30 Agustus 2018. Pelatihan yang disampaikan oleh Tim pengabdian dimulai dengan tanya jawab tentang pembelajaran berbasis Microsoft power point untuk mengetahui secara umum kebutuhan dan kemampuan awal guru. Para guru $90 \%$ telah menggunakan Windows 7, Ms. word 2007 dan 2010. Sedangkan Power Point belum pernah digunakan. Dalam pelatihan ini para peserta diajarkan bagaimana insert objek dan animasi dalam penggunaan PPT untuk mengajar.

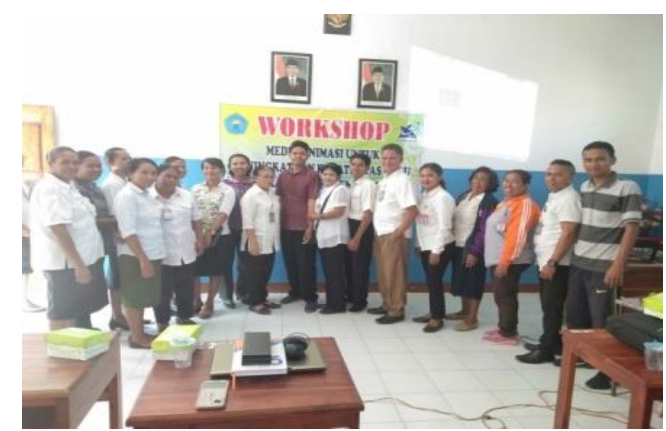

Gambar 1. Foto bersama setelah workshop hari pertama

Berdasarkan hasil evaluasi kebutuhan awal mereka, kegiatan pelatihan dimulai dengan penyampaian materi tentang pengenalan menu yang digunakan dalam powerpoint 2007 seperti insert gambar. Kegiatan ini memerlukan waktu yang agak lama kurang lebih 2 jam karena peserta belum terbiasa menggambar di Power PoinT. Untungnya kegiatan ini dibantu oleh 3 orang mahasiswa untuk mendampingi peserta dalam menggunakan power point. Kegiatan pelatihan dilanjutkan dengan memberikan materi insert animation dan custom animation. Setelah para peserta mampu membuat dan menggunakan PPT, hasil media yang dikerjakan bersama-sama dengan menggunakan Ms. Powerpoint 2007 seperti Gambar 2.

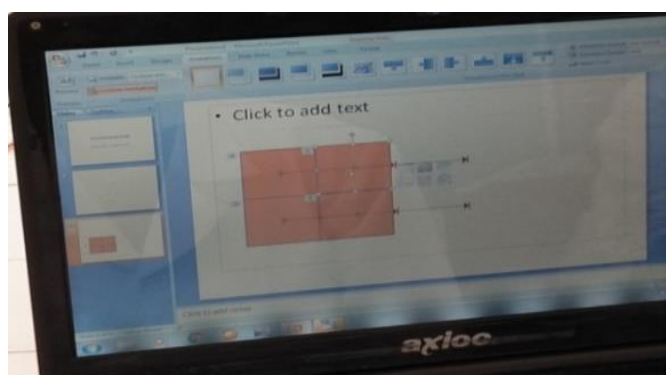

Gambar 2. Foto hasil kerja salah seorang guru peserta workshop hari pertama. 
Gambar 2 ini menunjukkan hasil kerja salah seorang guru SDN Kenari dalam hal membuat animasi gambar, menghitung luas persegi dengan ukuran sisi 2 satuan menggunakan custom animation. Hasil pengamatan dan penugasan menunjukkan bahwa 90\% guru SDN Kenari mampu membuat media animasi dengan menggunakan Microsoft PowerPoint. Berikut adalah hasil kerja guru-guru peserta dari tugas yang diberikan, yaitu membuat luas persegi dan persegi panjang dengan custom animation pada Gambar 3.

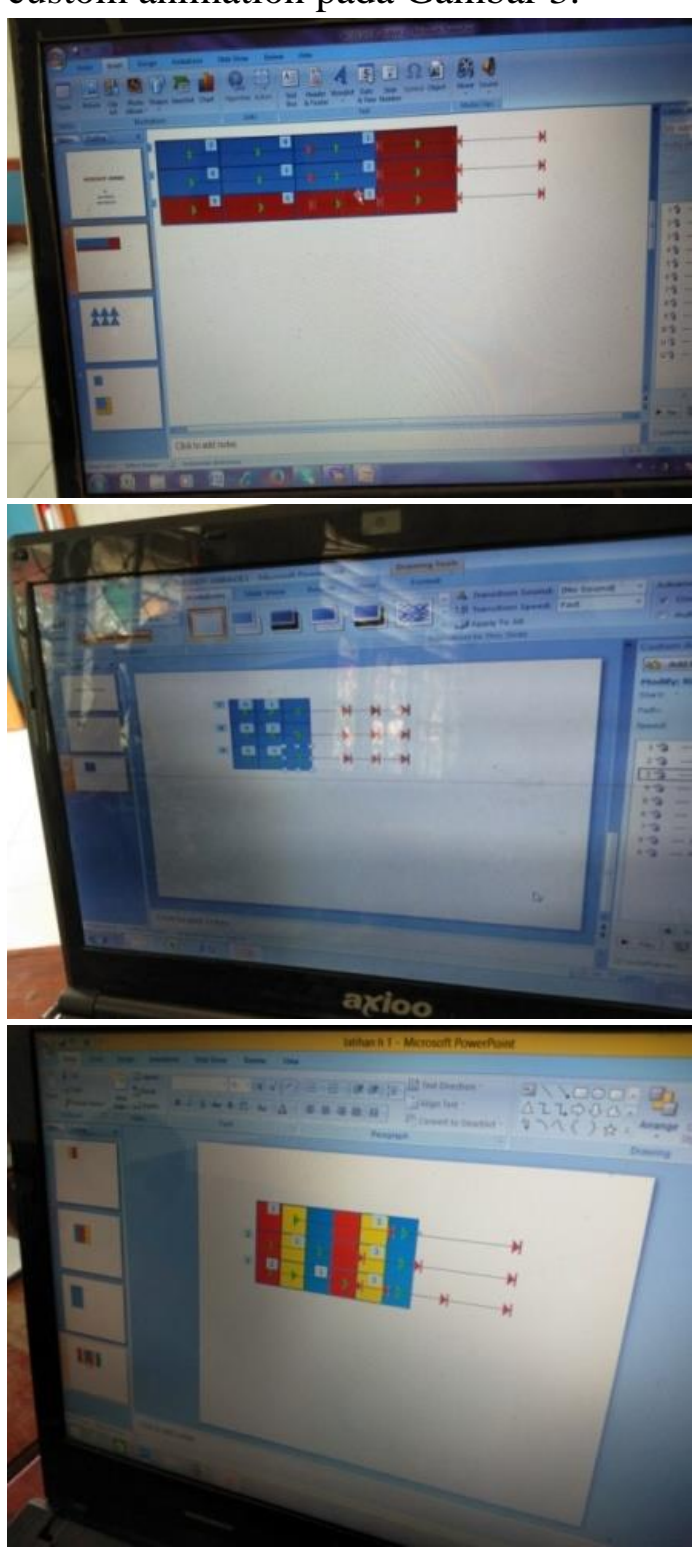

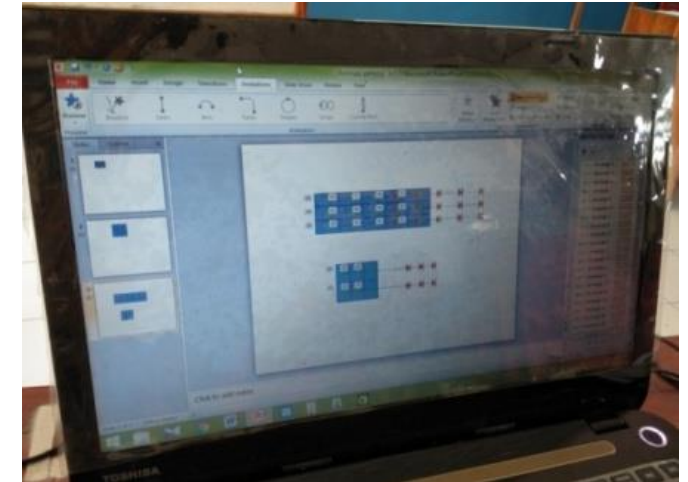

Gambar 3. Foto hasil kerja tugas kelompok guru peserta workshop hari pertama.

Gambar 3 ini menunjukkan hasil kerja tugas kelompok guru SDN Kenari dalam hal membuat animasi gambar, menghitung luas persegi dan persegi panjang dengan ukuran sisi berbedabeda menggunakan custom animation. Hasil penugasan menunjukkan bahwa $100 \%$ guru SDN Kenari mampu membuat media animasi dengan menggunakan Microsoft PowerPoint.

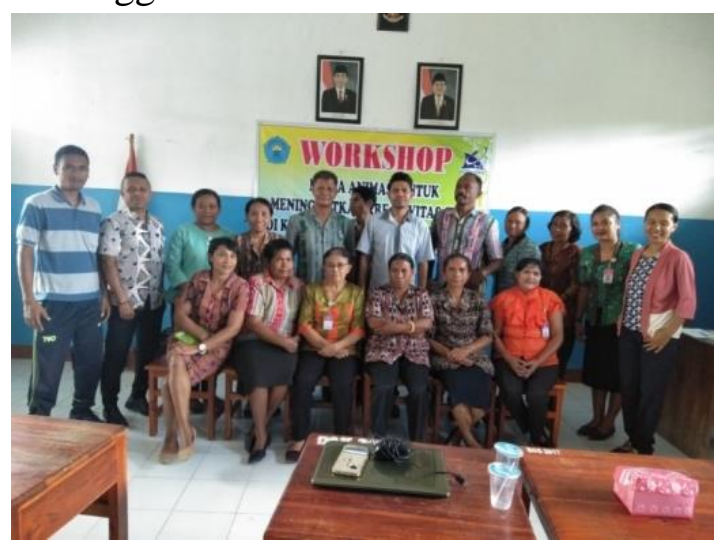

Gambar 4. Foto bersama setelah workshop hari kedua.

Pada hari kedua dilanjutkan dengan pelatihan menentukan luas bangun datar, segitiga sebarang menggunakan insert animation dan custom animation. Workshop pada hari kedua ini, guru tidak mengalami kesulitan karena hanya pengulangan materi yang sama, yaitu menggunakan 
custom animation. Sedangkan perbedaannya adalah gambar yang digerakkan adalah segitiga, menghitung luas segitiga sebarang. Berikut hasil kerja guru mitra pada Gambar 5.

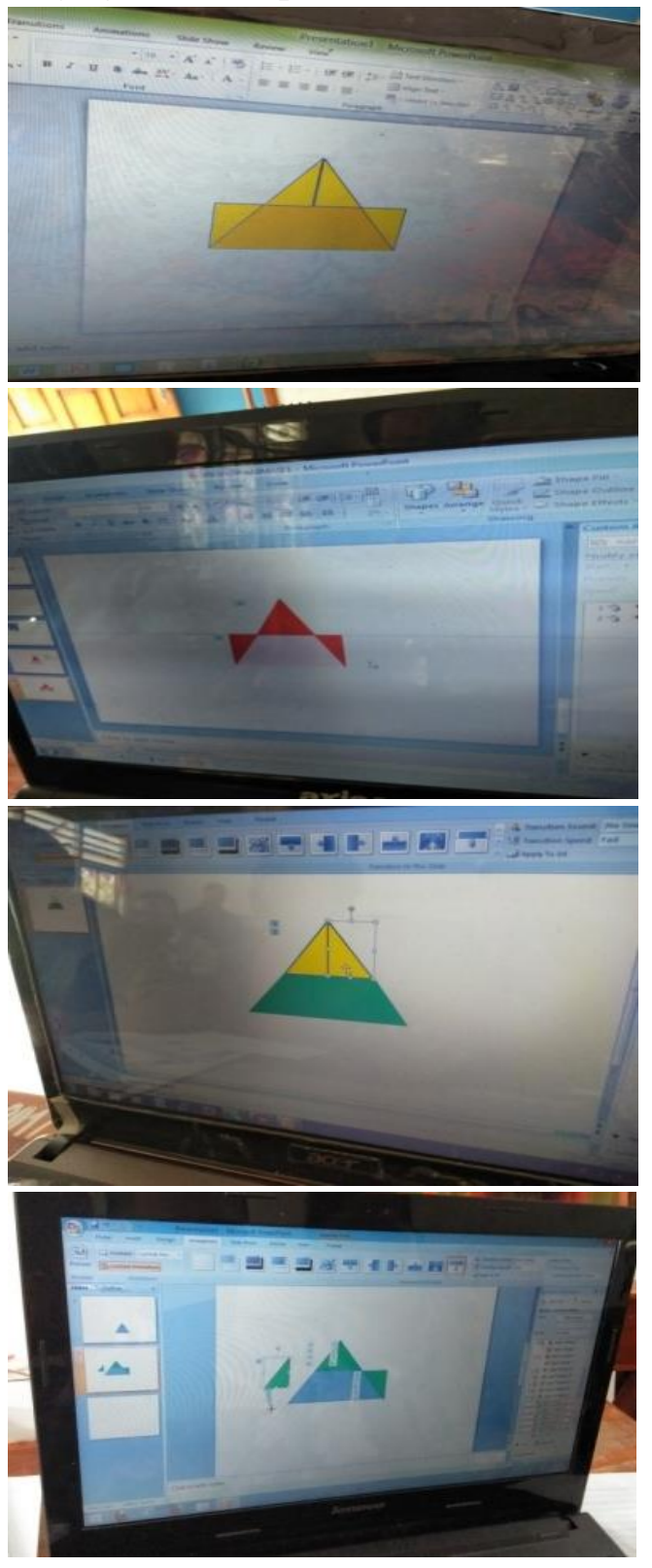

Gambar 5. Foto hasil kerja peserta workshop hari kedua.

Gambar 5 ini menunjukkan hasil kerja tugas kelompok guru SDN Kenari dalam hal membuat animasi luas segitiga sebarang menggunakan custom animation. Hasil penugasan menunjukkan bahwa 100\% guru SDN Kenari mampu membuat media animasi luas segitiga dengan menggunakan Microsoft PowerPoint.

2). Evaluasi dan refleksi

Dari hasil kuesioner yang diberikan dapat disimpulkan bahwa para peserta sangat senang dan tertarik untuk mengikuti kegiatan ini yang ditandai dengan antusias guru menghadiri setiap kegiatan sampai selesai, hasil produk animasi persegi dan segitiga yang mereka buat termasuk kategori baik. Selanjutnya para peserta berkeinginan dan berharap adanya kegiatan lanjutan.

\section{Pembahasan}

Workshop media animasi untuk meningkatan Kreatifitas Guru Sekolah Dasar telah diikuti 17 orang guru mitra dari SD Negeri Kenari Kelurahan Kefamenanu Tengah Kota Kefamenanu. Kegiatan ini dilaksanakan pada tanggal 29-30 Agustus 2018. Pada pelaksanaan guru diwajibkan membawa perangkat komputer supaya dapat langsung melakukan praktik pembuatan animasi. Setelah pelaksanaan pelatihan ini, setiap guru diminta untuk membuat sendiri animasi. berdasarkan buku petunjuk yang telah diberikan (lihat Gambar terlampir). Tim mendampingi pembuatan animasi hingga guru tersebut berhasil menyelesaikan proyek tugas yang telah dipandu dalam buku petunjuk. Pemilihan kompetensi dasar (matematika) menemukan luas bangun datar dan sifat-sifatnya bertujuan untuk menanamkan sikap mencintai matematika, menarik minat dengan menggunakan media animasi, sehingga 
matematika menjadi mata pelajaran yang menyenangkan.

Berdasarkan hasil evaluasi, setelah mendapatkan pelatihan selama 2 kali berturut-turut para guru sudah mampu membuat sendiri animasi luas persegi, persegi panjang, dan segitiga menggunakan power point yang kreatif sesuai standar sebagai media yang inovatif. Indikator capaian dari hasil kegiatan pengabdian adalah guru mampu memahami penggunaan Ms. Power point sebagai media pembelajaran dan guru kreatif membuat media animasi menggunakan custum animation yang ada di power point.

\section{Kesimpulan}

Kegiatan workshop yang dilakukan dalam dua hari ini telah menunjukkan peningkatan kreatifitas guru Sekolah Dasar dalam pembuatan media animasi untuk mendukung pembelajaran di kelas. Hal ini ditunjukkan dari hasil proyek animasi yang dibuat oleh guru. Guru-guru berhasil menyelesaikan proyek pembuatan animasi sesuai dengan panduan yang telah diberikan di petunjuk pelatihan. Kegiatan ini mendapat sambutan yang baik dari peserta. Hal ini dapat dilihat dari kehadiran 17 peserta dari 18 guru dan pegawai di SDN Kenari.

\section{Daftar Pustaka}

Alfiyah, H.Y., Fauziyah, A.N., \& Masfufah. 2016. Pengembangan Kapasitas Guru Melalui Pengembangan Media Pembelajaran Interaktif Berbasis Teknologi Informasi di MINU Waru Sidoarjo.
Jurnal Pendidikan Agama Islam Volume 4 Nomor 1 Mei 2016 Hal. $158-178$

Arikunto, S., dkk. 2012. Penelitian Tindakan Kelas. Bumi Angkasa: Jakarta.

Badri, N. \& Riasti, B. K. 2013. Pembuatan Media Pembelajaran Interaktif Pada Smk Negeri Tiga Jepara Dengan Materi Power Point 2007. Indonesian Jurnal on Computer Science SpeedIJCSS:10(3)

Ena,O.T. 2010. Membuat Media Pembelajaran Interaktif dengan Piranti Lunak Presentasi. https://triansyah.wordpress.com/201 0/07/23/membuat-mediapembelajaran-interaktif-denganpiranti-lunak-presentasi/

Karyati, F. 2016. Pengaruh Kreativitas Guru Terhadap Pemanfaatan Media Pembelajaran Tematik Al-Ulum Ilmu Sosial Dan Humaniora Volume 1 Nomor 2, April 2016.

Purwandari, E.P., Anggriani, K., \& Noperman, F. 2016. Peningkatan Keterampilan Guru SD Dalam Pembuatan Media Animasi Untuk Menanamkan Sikap Pelestarian Hewan Bagi Siswa. Jurnal Rekursif, Vol. 4 No. 3 September 2016.

Shabrina, L. 2012. Upaya meningkatkan pemahaman konsep dan daya kreatif siswa melalui media animasi. Skripsi. Universitas Pendidikan Indonesia: Bandung.

Sudianto, dkk. 2014. penggunaan media animasi dalam meningkatkan aktivitas belajar matematika Siswa Kelas VIII SMP Negeri 3 Galing. FKIP Untan: Kalimantan. 